\title{
Holoprosencephaly Type 2
}

National Cancer Institute

\section{Source}

National Cancer Institute. Holoprosencephaly Type 2. NCI Thesaurus. Code C74995.

A rare disorder characterized by the partial separation of the cerebral hemispheres. It is associated with mutations in the SIX3 gene. 